\title{
THE RELATIONSHIP BETWEEN POSITIVE AND NEGATIVE EMOTIONAL STATES AND MOTIVATION OF HIGH SCHOOL STUDENTS DOING SPORTS
}

\author{
A RELAÇÃO ENTRE ESTADOS EMOCIONAIS POSITIVOS E NEGATIVOS E A \\ MOTIVAÇÃO DOS ALUNOS DO ENSINO MÉDIO QUE PRATICAM ESPORTES
}

\author{
LA RELACIÓN ENTRE ESTADOS EMOCIONALES POSITIVOS Y NEGATIVOS Y \\ MOTIVACIÓN DE ESTUDIANTES DE BACHILLERATO HACIENDO DEPORTES
}

\author{
Melih BALYAN ${ }^{1}$ \\ Cemali ÇANKAYA ${ }^{2}$
}

\begin{abstract}
The aim of this research was to The Relationship Between Positive And Negative Emotional States And Motivation Of High School Students Doing Sports. The sample of the research consists of 441 students in total, 290 Male and 151 Female, studying at high schools. With the personal information form to determine demographic characteristics, the Panas scale which was developed by Watson et al. (1988) and adapted into Turkish by Gençöz (2000) and which examines emotional states with positive and negative dimensions, and The Sports Motivation Scale which was developed by Pelletier et al. (1995) and adapted into Turkish by Kazak (2004), were used. The data obtained were analyzed with SPSS 23.0 statistical package program. In the evaluation of the data, t-test for independent samples and One-way analysis of variance (ANOVA) tests for differences between groups and the "Tukey Post Hoc" test and Pearson Correlation test were used. As a result of the research; sportsspecific success and motivation levels of students who are constantly engaged in sports; significance levels were examined according to gender, age, education, income level, place of residence, duration of doing sports, doing sports with license, frequency of doing sports, and being interested in different branches, and it was seen that there was no statistically significant difference.
\end{abstract}

KEYWORDS: High school student. Athlete. Positive and negative emotions (panas). Motivation in sports.

RESUMO: O objetivo desta pesquisa foi a Relação entre os Estados Emocionais Positivos e Negativos e a Motivação de Alunos do Ensino Médio a Praticar Esportes. A amostra da pesquisa é composta por 441 alunos de ensino médio no total, 290 do sexo masculino e 151 do feminino. Com o formulário de informações pessoais para determinar as características demográficas, a escala Panas que foi desenvolvida por Watson et al. (1988) e adaptada para o turco por Gençöz (2000) e que examina estados emocionais com dimensões positivas e negativas, e a Escala de Motivação Esportiva que foi desenvolvida por Pelletier et al. (1995) e adaptada para o turco por Kazak (2004). Os dados obtidos foram analisados com o programa estatístico SPSS 23.0. Na avaliação dos dados foram utilizados o teste t para

1 Ege University (EGE), İzmir - Turkey. Associate Professor, Faculty of Sport Sciences. ORCID: https://orcid.org/0000-0002-3833-7456. E-mail: melihbalyan@hotmail.com

${ }^{2}$ Istanbul Sabahattin Zaim University (IZU), Istanbul - Turkey. Professor, Faculty of Sport Sciences. ORCID: https://orcid.org/0000-0001-7973-5816. E-mail: cemali.cankaya@izu.edu.tr

RPGE- Revista on line de Política e Gestão Educacional, Araraquara, v. 25, n. 3, p. 2567-2588, Sep./Dec. 2021. e-ISSN: 1519-9029 
amostras independentes e os testes de análise de variância (ANOVA) para diferenças entre grupos e o teste "Tukey Post Hoc" e o teste de Correlação de Pearson. Como resultado da pesquisa; niveis de sucesso e motivação específicos de esportes de alunos que estão constantemente envolvidos em esportes; os niveis de significância foram examinados de acordo com sexo, idade, escolaridade, nível de renda, local de residência, tempo de prática de esportes, prática de esportes com licença, frequência de prática de esportes e interesse por ramos diferentes, e foi verificado que não houve diferença significante.

PALAVRAS-CHAVE: Aluno do ensino médio. Atleta. Emoções positivas e negativas (panas). Motivação no esporte.

RESUMEN: El objetivo de esta investigación fue conocer la relación entre los estados emocionales positivos y negativos y la motivación de los estudiantes de secundaria que practican deporte. La muestra de la investigación está formada por 441 estudiantes en total, 290 hombres y 151 mujeres, que cursan estudios de secundaria. Con el formulario de información personal para determinar características demográficas, la escala Panas que fue desarrollada por Watson et al. (1988) y adaptado al turco por Gençöz (2000) y que examina estados emocionales con dimensiones positivas y negativas, y The Sports Motivation Scale que fue desarrollada por Pelletier et al. (1995) y adaptado al turco por Kazak (2004). Los datos obtenidos se analizaron con el paquete estadístico SPSS 23.0. En la evaluación de los datos se utilizó la prueba $t$ para muestras independientes y las pruebas de análisis de varianza unidireccional (ANOVA) para diferencias entre grupos y la prueba "Tukey Post Hoc" y la prueba de correlación de Pearson. Como resultado de la investigación; los niveles de motivación y éxito deportivos específicos de los estudiantes que participan constantemente en los deportes; Se examinaron los niveles de significancia según sexo, edad, educación, nivel de ingresos, lugar de residencia, duración de la práctica deportiva, práctica deportiva con licencia, frecuencia de práctica deportiva, interés por las diferentes ramas, y se observó que estadísticamente no existía diferencia significativa.

PALABRAS CLAVE: Estudiante de bachillerato. Deportista. Emociones positivas y negativas (panas). Motivación en el deporte.

\section{Introduction}

When the origin of the term "motivation" is investigated, we come across; motus, which means movement in Latin (ADAIR, 2003). The reasons underlying the behaviors of human beings throughout their lives are discussed within the framework of the concept of motive (HAZAR et al., 2018). Motivation, which directs individuals to behavior and is the most important concept in shaping behaviors, is defined as the force that directs behavior (ROBERTS et al., 2007). Motivation creates the stimulation, direction and continuity of the behavior (FRANKEN, 1994).

Motivation can be defined as various internal and external factors that push the organism to the behavior, determine the regularity and continuity of these behaviors, give 
direction and purpose to the behavior, and the mechanisms that ensure their functioning (AYDIN, 2001). When our motives are examined in general, they are divided into two main categories. Extrinsic motivation and intrinsic motivation. Extrinsic motivation is not a situation that is directly related to the athlete himself. It is the positive or negative effects of various situations occurring in the external environment on the athlete. In other words, extrinsic motivation is self-created behavior (LUG, 1995). Extrinsic motivation includes influences from outside the individual. Extrinsic motivation is reinforcement that can have negative and positive effects through other people, increase or decrease the likelihood of repetition of the behavior, and carry material and moral values. External rewards (medals, cups, money, etc.) can come from material means, as well as from intangible resources (to gain respect, appreciation, praise, etc.) (TÜRKMEN, 2005).

On the other hand, intrinsic motivation is the response to the needs of the person. Curiousty, knowing, wish to be sufficient and desire to develop can be given as examples of internal motives (SELÇUK, 1996). Intrinsic motivation, in short, is self-motivation. Intrinsically motivated people have an intrinsic hunger to be resourceful. These people have the ability to manage themselves in order to be successful (NICHOLLS, 1992). An intrinsically motivated person transforms thought into action, sets goals and takes action to achieve them (GEORGE, 1997).

Emotion: The state of feeling or consciousness that is caused by an external stimulant feature (sound, smell, color, shape, temperature, taste) or a change in the human body (hunger, thirst, nausea, sexual excitement) (BUDAK, 2001). Positive Emotion: It is the state that people reflect themselves as enthusiastic, active, excited, alert. Positive emotionality includes curious (interested), excited, strong, enthusiastic and alert (alive) emotions (WATSON et al., 1988). Negative Emotion: Includes a variety of impulsive emotional states such as anger, contempt, disgust, guilt, fear, and timidity. It is expressed as the general measure of responsibility that creates personal distress and does not give pleasure to people (WATSAN, 1988). According to Myers and Derakshan (2004), emotion is defined as a psychophysiological whole that occurs when cognitive processes in the individual affect environmental processes. Emotions, which are handled with different dimensions according to different theoretical approaches, affect individuals in many areas (GROSS, 1999). It is stated that emotions have many effects on the decision-making process, such as preparing motor reactions, improving learning, and regulating social behaviors. 
Sport allows the individual to get rid of his own narrow world and to be in dialogue with people from other people, beliefs and thoughts, to be influenced by them and to influence them. With this aspect, it can be said that sport supports the establishment and reinforcement of new friendships and social cohesion (BUĞDAYCI, 2000). Achievement motivation approach sees motivation situations as the basis of sportive behavior. These motivation situations are named as the motivation to approach success and the motivation to avoid failure (DOĞAN, 2005). If the reason for motivation differences can be understood, it may be easier to motivate people in the positive direction. Motivation for success in sports emerges as a result of the increase in the expectations of the athlete for the future. The pleasure and satisfaction of accomplishing a job creates new demands and new expectations in the athlete for future success. This motivation is called achievement motivation in sports (TURHAN, 2009). Ntuomanis (2005) stated that students who are intrinsically motivated in physical education classes enjoy the lessons and are not bored; asserted that the intrinsic motivation experienced in physical education and sports classes is the most determining factor in gaining the habit of leading a physically active life after school years. As the job satisfaction of individuals working in sports environments increases, the benefit they will provide within the organization increases (SUNAY et al., 2020). The fact that hearing-impaired students to devote significant amount of time on physical education and sports activities, raising awareness in the society, representing their country in the Paralympic games shows that they have a positive attitude towards physical education and sports (DALBUDAK; YIGIT, 2019).

Today, physical education and sports are conscious and planned activities that aim at the physical, social and emotional development of human beings, who are the main source of the growing generations, and are accepted as an integral and complementary part of general education (YILDIRAN, 1996). While motivation in sports is an important factor that complements each other, it is one of the main factors that strengthen the focus and desire to win in order to reach the goals of the athletes. People sometimes feel sad and unhappy. Leaving your job, losing a loved one or not being successful are life events that cause sadness. (ACAR et al., 2017). The athlete who loses the match does not enjoy this situation, but starts to think differently after getting through a lot with the support of his trainer and relatives (ALAEDDINOĞLU, 2021). 


\section{Methodology}

In this research, as data collection tools, Personal Information Form, prepared by the researcher, the Panas scale which was developed by Watson et al. (1988) and adapted into Turkish by Gençöz (2000) and which examines emotional states with positive and negative dimensions, and The Sports Motivation Scale which was developed by Pelletier et al. (1995) and adapted into Turkish by Kazak (2004), were used.

\section{Data Analysis}

\section{1) Panas Scale (Positive and Negative Affect Scale)}

Each question in the Panas Scale can be scored between 1 and 5 and there are 20 questions. 1: very little, 2: a little, 3: mean, 4: quite, and 5: a lot. A score between 20 and 100 can be obtained from the scale. If the total score is close to 100 , it means that the individual has had a lot of emotional intensity in the last two weeks, while a score close to 20 means that the emotional intensity is low. The scale has two basic sub-dimensions. It consists of 10 statements in two sub-dimensions, so the total score that can be obtained for both subdimensions is between 10 and 50. A total score close to 10 indicates low positive or negative emotion, and close to 50 indicates the intensity of these emotions.

1) Positive emotion: questions $1-3-5-9-10-12-14-16-17-19$.

2) Negative emotion: questions $2-4-6-7-8-11-13-15-18-20$.

Table 1 - Descriptive Summary Statistics of "Panas Scale" and Subscale Scores

\begin{tabular}{lccccccc}
\hline $\begin{array}{l}\text { Scale and } \\
\text { Subscales }\end{array}$ & Min. & Max. & Mean & $\begin{array}{c}\text { Standard } \\
\text { Deviation }\end{array}$ & Skewness & Kurtosis & $\begin{array}{c}\text { Cronbach's } \\
\text { Alpha }\end{array}$ \\
\hline Panas Scale & 1 & 0 & 56,6349 & 9,1713 & 0,277 & 0,413 & 0,896 \\
\hline Positive Emotion & 0 & 0 & 36,5760 & 7,3527 & $-0,766$ & 0,771 & 0,827 \\
Negative Emotion & 0 & 3 & 20,0590 & 7,2907 & 0,892 & 0,463 & 0,815 \\
\hline
\end{tabular}

Source: Prepared by the authors

- Positive emotion sub-dimension total score mean is 36,5760 and standard deviation is 7,3527. The lowest score is 10 and the highest score is 50 . The skewness value of the total score values is $-0,766$ and the kurtosis value is 0,771 .

- Negative emotion sub-dimension total score mean is 20,0590 and standard deviation is 7,2907 . The lowest score is 10 and the highest score is 43 . The skewness value of the total score values is 0,892 and the kurtosis value is 0,463 . 
- Panas scale total score mean is 56,6349 and standard deviation is 9.1713. The lowest score is 31 and the highest score is 90 . The skewness value of the total score values is 0,277 and the kurtosis value is 0,413 .

When the skewness and kurtosis values of the Scale and Subscales are examined, it is seen that all of them are between -2 and +2 . If the skewness and kurtosis values are between 2 and +2 , the assumption of normal distribution can be accepted for the scale score values. (GEORGE; MALLERY, 2010). The Cronbach's Alpha value, which measures the reliability of the "Panas Scale" in which 441 individuals participated, was found $\alpha=0,896$. In addition, the Cronbach's Alpha value of the positive affect sub-dimension was $\alpha=0,827$ and the Cronbach's Alpha value of the negative affect sub-dimension was $\alpha=0,815$. It is concluded that the Panas Scale and its Sub-Dimensions are quite reliable and acceptable.

The Interpretation of the Relationship Between the "Panas Scale" and the SubDimension Total Scores with the Pearson Correlation Coefficient

Table 2 - The Relationship Between Panas Scale and Sub-Dimensional Total Scores

\begin{tabular}{|c|c|c|c|}
\hline & 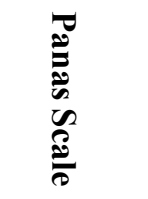 & 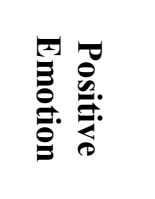 & 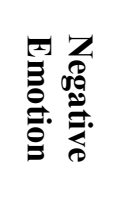 \\
\hline Panas Scale & 1,000 & $\begin{array}{c}0,630^{* *} \\
(0,000)\end{array}$ & $\begin{array}{c}0,622 * * \\
(0,000)\end{array}$ \\
\hline Positive Emotion & $\begin{array}{c}0,630^{* *} \\
(0,000)\end{array}$ & 1,000 & $\begin{array}{c}0,215 * * \\
(0,000)\end{array}$ \\
\hline Negative Emotion & $\begin{array}{c}0,622^{* *} \\
(0,000)\end{array}$ & $\begin{array}{c}-0,215^{* *} \\
(0,000)\end{array}$ & 1,000 \\
\hline
\end{tabular}

*Correlation is significant at the 0,01 level

Source: Prepared by the authors

- Looking at the table, there is a 99\% confidence level between the "Panas Scale" scores and the "positive emotion" $(p=0,000)$ and "negative emotion" $(p=0,000)$ subdimension scores (one increases as the other increases, or one decreases while the other decreases), it is concluded that there is a relationship.

- It is concluded that there is an inverse relationship between "positive emotion" scores and "negative emotion" ( $\mathrm{p}=0,000)$ sub-dimension scores at $99 \%$ confidence level. 
While positive emotions of individuals are intense, their negative emotions are decreasing.

\section{2) Sports Motivation Scale}

Each question in the Sports Motivation Scale can be scored between 1 and 7 and there are 28 questions. An option from 1 to 7 is marked, with 1: not appropriate, 4: moderately appropriate and 7: completely appropriate. A score between 28 and 196 can be obtained from the scale. The higher the total score, the higher the individuals' motivation for sports is.

The scale has six basic sub-dimensions.

1) Knowing and achieving: questions $2-4-8-12-15-20-23-27$ (between 8 and 56 points can be obtained).

2) Stimulating living: questions $1-13-18-25$ (between 4 and 28 points can be obtained).

3) External regulation: $6-10-16-22$ questions (between 4 and 28 points can be obtained).

4) Introjection: 9 - $14-21-26$ questions (between 4 and 28 points can be obtained).

5) Identification: $7-11-17-24$ questions (between 4 and 28 points can be obtained).

6) Amotivation: $3-5-19-28$ questions (between 4 and 28 points can be obtained) items of the non-motivation sub-dimension are reverse scored. The higher the unmotivated sub-dimension score, the higher the individual's motivation.

Table 3 - Descriptive Summary Statistics of Sports Motivation Scale and Subscale Scores

\begin{tabular}{|c|c|c|c|c|c|c|c|c|}
\hline $\begin{array}{l}\text { Scale and } \\
\text { Subscales }\end{array}$ & Min. & Max. & & Mean & $\begin{array}{l}\text { Standard } \\
\text { Deviation }\end{array}$ & Skewness & Kurtosis & $\begin{array}{c}\text { Cronbach's } \\
\text { Alpha }\end{array}$ \\
\hline SG Scale & 7 & 90 & 1 & 141,5556 & 25,8944 & $-0,338$ & $-0,516$ & 0,901 \\
\hline $\begin{array}{l}\text { Knowing and } \\
\text { Achieving }\end{array}$ & 1 & 6 & 5 & 42,8776 & 9,9221 & $-0,556$ & $-0,404$ & 0,875 \\
\hline Stimulating Living & 4 & 8 & 2 & 21,5805 & 4,9738 & $-0,654$ & $-0,213$ & 0,750 \\
\hline External Regulation & 4 & 8 & 2 & 17,2721 & 5,8720 & $-0,198$ & $-0,521$ & 0,785 \\
\hline Introjection & 4 & 8 & 2 & 21,0159 & 5,1285 & $-0,655$ & $-0,023$ & 0,698 \\
\hline Identification & 4 & 8 & 2 & 19,1814 & 5,5106 & $-0,246$ & $-0,577$ & 0,745 \\
\hline Amotivation & 4 & 8 & 2 & 19,6281 & 4,1699 & $-0,854$ & 0,788 & 0,683 \\
\hline
\end{tabular}

Source: Prepared by the authors 
- Knowing and achieving sub-dimension total score mean is 42,8776 and standard deviation is 9,9221 . The lowest score is 14 and the highest score is 56 . The skewness value of the total score values is $-0,556$ and the kurtosis value is $-0,404$.

- The total score of the sub-dimension of stimulating living is 21,5805 and its standard deviation is 4,9738 . The lowest score is 4 and the highest score is 28 . The skewness value of the total score values is $-0,654$ and the kurtosis value is $-0,213$.

- External regulation sub-dimension total score mean is 17,2721 and standard deviation is 5,8720 . The lowest score is 4 and the highest score is 28 . The skewness value of the total score values is $-0,198$ and the kurtosis value is $-0,521$.

- Introjection sub-dimension total score mean is 21,0159 and standard deviation is 5,1285 . The lowest score is 4 and the highest score is 28 . The skewness value of the total score values is $-0,655$ and the kurtosis value is $-0,023$.

- Identification sub-dimension total score mean is 19,1814 and standard deviation is 5,5106 . The lowest score is 4 and the highest score is 28 . The skewness value of the total score values is $-0,246$ and the kurtosis value is $-0,577$.

- In the sub-dimension of amotivation, the total score mean is 19,6281 and the standard deviation is 4,1699 . The lowest score is 4 and the highest score is 28 . The skewness value of the total score values is $-0,854$ and the kurtosis value is 0,788 .

- The total mean score of the SM scale is 141,5556 and its standard deviation is 25,8944 . The lowest score is 74 and the highest score is 190 . The skewness value of the total score values is $-0,338$ and the kurtosis value is $-0,516$.

When the skewness and kurtosis values of the Scale and Subscales are examined, it is seen that all of them are between -2 and +2 . If the skewness and kurtosis values are between 2 and +2 , the assumption of normal distribution can be accepted for the scale score values (George And Mallery, 2010). The Cronbach's Alpha value, which measures the reliability of the SM Scale, in which 441 individuals participated, was found to be $\alpha=0,901$. In addition, Cronbach's Alpha value $\alpha=0,875$ for knowing and achieving sub-dimension, Cronbach's Alpha value for stimulating living sub-dimension $\alpha=0,750$, and Cronbach's Alpha value for external regulation sub-dimension. Value of $\alpha=0,785$, Cronbach's Alpha value of introjection sub-dimension $\alpha=0,698$, Cronbach's Alpha value $\alpha=0,745$ of identification sub-dimension and Cronbach's Alpha value $\alpha=0,683$ of amotivation sub-dimension. 


\section{Interpretation of the Relationship between the "SM scale" and the Sub-Dimension Total Scores with the Pearson Correlation Coefficient}

Table 4 - The Relationship Between the "Sports Motivation Scale" and the Sub-Dimension Total Scores

\begin{tabular}{|c|c|c|c|c|c|c|c|}
\hline & $\begin{array}{l}n \\
3 \\
n \\
0 \\
\frac{0}{0}\end{array}$ & 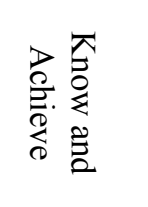 & : & 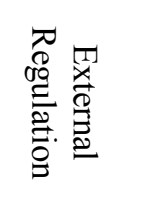 & 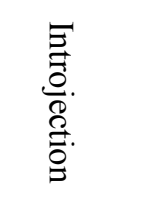 & 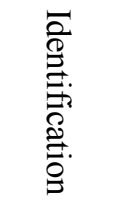 & 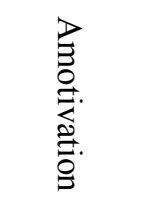 \\
\hline SM scale & 1,000 & $\begin{array}{c}0,881 * * \\
(0,000)\end{array}$ & $\begin{array}{c}0,779 * * \\
(0,000)\end{array}$ & $\begin{array}{c}0,690 * * \\
(0,000)\end{array}$ & $\begin{array}{c}0,802 * * \\
(0,000)\end{array}$ & $\begin{array}{c}0,790 * * \\
(0,000)\end{array}$ & $\begin{array}{c}0,182 * * \\
(0,000)\end{array}$ \\
\hline $\begin{array}{l}\text { Knowing and } \\
\text { Achieving }\end{array}$ & $\begin{array}{c}0,881 * * \\
(0,000)\end{array}$ & 1,000 & $\begin{array}{c}0,685^{* *} \\
(0,000)\end{array}$ & $\begin{array}{c}0,473 * * \\
(0,000)\end{array}$ & $\begin{array}{c}0,609 * * \\
(0,000)\end{array}$ & $\begin{array}{c}0,578^{* *} \\
(0,000)\end{array}$ & $\begin{array}{c}0,097 \\
(0,053)\end{array}$ \\
\hline $\begin{array}{l}\text { Stimulating } \\
\text { Living }\end{array}$ & $\begin{array}{c}0,779 * * \\
(0,000)\end{array}$ & $\begin{array}{c}0,685^{* *} \\
(0,000)\end{array}$ & 1,000 & $\begin{array}{c}0,375^{* *} \\
(0,000)\end{array}$ & $\begin{array}{c}0,561 * * \\
(0,000)\end{array}$ & $\begin{array}{c}0,557^{* *} \\
(0,000)\end{array}$ & $\begin{array}{c}0,061 \\
(0,202)\end{array}$ \\
\hline $\begin{array}{c}\text { External } \\
\text { Regulation }\end{array}$ & $\begin{array}{c}0,690^{* *} \\
(0,000)\end{array}$ & $\begin{array}{c}0,473^{* *} \\
(0,000)\end{array}$ & $\begin{array}{c}0,375^{* *} \\
(0,000)\end{array}$ & 1,000 & $\begin{array}{c}0,529 * * \\
(0,000)\end{array}$ & $\begin{array}{c}0,613^{* *} \\
(0,000)\end{array}$ & $\begin{array}{c}-0,155^{* *} \\
(0,001)\end{array}$ \\
\hline Introjection & $\begin{array}{c}0,802 * * \\
(0,000)\end{array}$ & $\begin{array}{c}0,609 * * \\
(0,000)\end{array}$ & $\begin{array}{c}0,561 * * \\
(0,000)\end{array}$ & $\begin{array}{c}0,529 * * \\
(0,000)\end{array}$ & 1,000 & $\begin{array}{c}0,600 * * \\
(0,000)\end{array}$ & $\begin{array}{c}0,095 \\
(0,056)\end{array}$ \\
\hline Identification & $\begin{array}{c}0,790^{* *} \\
(0,000)\end{array}$ & $\begin{array}{c}0,578^{* *} \\
(0,000)\end{array}$ & $\begin{array}{c}0,557^{* *} \\
(0,000)\end{array}$ & $\begin{array}{c}0,613 * * \\
(0,000)\end{array}$ & $\begin{array}{c}0,600 * * \\
(0,000)\end{array}$ & 1,000 & $\begin{array}{l}-0,055 \\
0,246\end{array}$ \\
\hline Amotivation & $\begin{array}{c}0,182 * * \\
(0,000)\end{array}$ & $\begin{array}{c}0,097 \\
(0,053)\end{array}$ & $\begin{array}{c}0,061 \\
(0,202)\end{array}$ & $\begin{array}{c}-0,155^{* *} \\
(0,001)\end{array}$ & $\begin{array}{c}0,095 \\
(0,056)\end{array}$ & $\begin{array}{c}-0,055 \\
0,246\end{array}$ & 1,000 \\
\hline
\end{tabular}

*Correlation is significant at the 0,01 level

Source: Prepared by the authors

- There is an inverse relationship between amotivation sub-dimension and external regulation sub-dimension $(\mathrm{p}=0,001)$. However, no significant relationship was found between the amotivation sub-dimension and the other sub-dimensions. There is a statistically significant positive correlation between all other sub-dimensions.

- Considering the correlation between the sub-dimensions and the SM scale, there is a positive relationship between all sub-dimensions and the SM scale. As the subdimension scores increase, the SM scale scores also increase. 


\section{Results}

Table 5 - Distribution of Demographic Characteristics of Individuals Participating in the Research

\begin{tabular}{lll}
\hline Variable & Frequency (n) & Percentage (\%) \\
\hline Gender & 151 & 34,2 \\
Female & 290 & 65.8 \\
Male & 441 & 100,0 \\
Total & & \\
& & 31.1 \\
Age & 137 & 30.4 \\
15 & 134 & 29,9 \\
16 & 132 & 8.6 \\
17 & 38 & 100,0 \\
18 & 441 & \\
Total & & 45,8 \\
& & 54.2 \\
Sport branch & 202 & 100,0 \\
Team Sports & 239 & \\
Total & 441 & 66,7 \\
\hline Active Sports Time & & 33,3 \\
$0-5$ years & 294 & 100,0 \\
6 years and more & 147 & \\
Total & 441 & 25,2 \\
\hline How Many Days A Week Do You Do Sports? & & 46.0 \\
1-2 days & 111 & 25,6 \\
3-4 days & 203 & 3,2 \\
5-6 days & 113 & 100,0 \\
Toys & 14 & \\
\hline Sotal & 441 & \\
\hline
\end{tabular}

Source: Prepared by the authors

- Of the 441 individuals, 151 (34.2\%) are female and 290 (65.8\%) are male.

- $137(31.1 \%)$ are 15 years old, 134 (30.4\%) 16 years old, 132 (29.9\%) 17 and 38 $(8.6 \%) 18$ years old.

- 202 (45.8\%) engage in individual sports, while 239 (54.2\%) engage in team sports.

- While $294(66.7 \%)$ of them have been actively involved in sports for a maximum of 5 years, $147(33.3 \%)$ have been actively involved in sports for 6 years or more.

- $111(25.2 \%)$ 1-2 days a week, 203 (46.0\%) 3-4 days a week, $113(25.6 \%)$ 5-6 days a week and $14(3,2 \%)$ do sport 7 days a week. 


\section{Analysis of "Panas Scale" and sub-dimension scores according to students' demographic characteristics}

In the tables below, summary statistics based on the demographic characteristics of the scale score means are given. In addition, since the mean scores of the scale and subscales provided the assumption of normal distribution, independent samples were tested with t-test and the differences between the groups were tested with the One-way analysis of variance (ANOVA) tests, and from which groups the differences originated was tested with the Tukey Post Hoc test.

Table 6. Findings Regarding the Panas Scale and Sub-Dimension Scores by Gender of the Participants

\begin{tabular}{lcccc}
\hline \multirow{2}{*}{ Gender } & & Positive Emotion & Negative Emotion & Panas Scale \\
\hline \multirow{2}{*}{ Female } & Mean & 33,4901 & 21,5298 & 55,0199 \\
& St. Deviation & 8,1730 & 7,5919 & 9,6922 \\
\hline \multirow{2}{*}{ Male } & Mean & 38,1828 & 19,2931 & 57,4759 \\
& St. Deviation & 6,3303 & 7,0210 & 8,7882 \\
\hline p- value & & $0.000^{*}$ & $0,002^{*}$ & $0,007^{*}$ \\
\hline
\end{tabular}

Source: Prepared by the authors

There is a significant difference at $\% 95$ confidence level in the Panas scale and subdimension scores of individuals according to their gender $(\mathrm{p}<0.05)$. Accordingly, men's positive emotion intensity is higher than women's, and women's negative emotion intensity is higher than men's. Also, men have higher Panas scale scores than women and men have higher overall emotional intensity than women.

Table 7 - Findings Regarding the Panas Scale and Sub-Dimension Scores by Age of the Participants

\begin{tabular}{lcccc}
\hline Age & & $\begin{array}{c}\text { Positive } \\
\text { Emotion }\end{array}$ & Negative Emotion & Panas Scale \\
\hline \multirow{2}{*}{$\mathbf{1 5}$} & Mean & 36,4453 & 18,9781 & 55,4234 \\
& St. Deviation & 6,2906 & 7,3118 & 8,0483 \\
\hline \multirow{2}{*}{$\mathbf{1 6}$} & Mean & 36,2836 & 20,0597 & 56,3433 \\
& St. Deviation & 7,9949 & 7,4255 & 9,3552 \\
\hline \multirow{2}{*}{17} & Mean & 36,6515 & 20,6970 & 57,3485 \\
& St. Deviation & 7,8214 & 7,2858 & 10,0114 \\
\hline
\end{tabular}


p-value

0,719

0,110

0,066

Source: Prepared by the authors

Panas scale and sub-dimension scores of individuals do not show a statistically significant difference according to their age $(\mathrm{p}>0,05)$.

Table 8 - Findings Regarding the Panas Scale and Sub-Dimension Scores of the Participants by Sport Branch

Sport branch

Positive Emotion

Negative Emotion

Panas Scale

$\begin{array}{lll}\text { Mean } & 35,6287 & 19,5743\end{array}$

Individual Sports

$\begin{array}{cccc}\text { St. Deviation } & 7,3190 & 6,9287 & 8,5514 \\ \text { Mean } & 37,3766 & 20,4686 & 57,8452\end{array}$

Team Sports

St. Deviation

7,3008

7,5735

9,5149

p- value

$0,013^{*}$

0,200

0,002

Source: Prepared by the authors

The positive emotion and panas scale total scores of individuals engaged in team sports are higher than individuals engaged in individual sports $(\mathrm{p}<0,05)$. Individuals' negative emotion scores do not differ according to the sport branch $(\mathrm{p}>0,05)$.

Table 9 - Findings Regarding the Participants' Panas Scale and Sub-Dimension Scores by Active Sports Year

Active Sports Time

Positive Emotion Negative Emotion

Panas Scale

\begin{tabular}{lcccc}
\hline \multirow{2}{*}{ 0 - 5 years } & Mean & 36,1973 & 20,0884 & 56,2857 \\
& St. Deviation & 7,2842 & 7,3794 & 9,0802 \\
\hline \multirow{2}{*}{ 6 years and more } & Mean & 37,3333 & 20,0000 & 57,3333 \\
& St. Deviation & 77,4551 & 7,1347 & 9,3430 \\
\hline p- value & & 0,126 & 0,905 & 0,259 \\
\hline
\end{tabular}

Source: Prepared by the authors

Individuals' Panas scale and sub-dimension scores do not differ significantly according to their active sports duration $(\mathrm{p}>0,05)$. 
Table 10 - Findings Regarding the Participants' Panas Scale and Sub-Dimension Scores According to the Number of Sports Days in a Week

\begin{tabular}{lcccc}
\hline $\begin{array}{l}\text { Number of sports } \\
\text { days per week }\end{array}$ & Mean & 34,3153 & 21,0360 & Panas Scale \\
\hline \multirow{2}{*}{ 1-2 days } & St. Deviation & 8,1875 & 7,2412 & 55,3514 \\
& Mean & 36,8079 & 19,8966 & 9,2565 \\
\hline \multirow{2}{*}{ 3-4 days } & St. Deviation & 6,8619 & 7,3830 & 56,7044 \\
& Mean & 37,5714 & 19,6372 & 9,1652 \\
\hline \multirow{2}{*}{ 5-6 days } & St. Deviation & 5,7741 & 7,0420 & 57,8938 \\
& Mean & 36,5760 & 18,0714 & 8,8835 \\
\hline \multirow{2}{*}{ 7 days } & St. Deviation & 7,3527 & 8,1756 & 55,6429 \\
& & $0,001 *$ & 0,320 & 10,3819 \\
\hline p- value & & & & 0,214 \\
\hline Source Prive Emotion & Negative Emotion &
\end{tabular}

Source: Prepared by the authors

Individuals' Panas scale and negative emotion scores do not differ according to the number of sports they do per week $(p>0,05)$. However, it was concluded that as the number of days of exercise in a week increased, the positive emotions of individuals also increased.

\section{Analysis of "sm scale" and sub-dimension scores according to students' demographic characteristics}

In the tables below, summary statistics based on the demographic characteristics of the scale score means are given. In addition, since the mean scores of the scale and subscales provided the assumption of normal distribution, independent samples were tested with $\mathrm{t}$-test and the differences between the groups were tested with the One-way analysis of variance (ANOVA) tests, and from which groups the differences originated was tested with the Tukey Post Hoc test.

Table 11 - Findings Regarding the Sports Motivation Scale and Sub-Dimension Scores of Participants by Gender

\begin{tabular}{|c|c|c|c|c|c|c|c|c|}
\hline $\begin{array}{l}\text { Gende } \\
\mathbf{r}\end{array}$ & & $\begin{array}{l}\text { Knowin } \\
\text { g } \\
\text { Achievin } \\
\quad \mathrm{g}\end{array}$ & $\begin{array}{l}\text { Stimulati } \\
\text { ng Living }\end{array}$ & $\begin{array}{c}\text { External } \\
\text { Regulatio } \\
\mathbf{n}\end{array}$ & $\begin{array}{l}\text { Introjecti } \\
\text { on }\end{array}$ & $\begin{array}{l}\text { Identificati } \\
\text { on }\end{array}$ & $\begin{array}{l}\text { Amotiv } \\
\text { ation }\end{array}$ & SM Scale \\
\hline $\begin{array}{l}\text { Femal } \\
\text { e }\end{array}$ & $\begin{array}{c}\text { Mean } \\
\text { St. } \\
\text { Deviatio } \\
\text { n }\end{array}$ & $\begin{array}{l}41,8543 \\
10,1017\end{array}$ & $\begin{array}{c}21,0728 \\
5,4099\end{array}$ & $\begin{array}{c}15,8344 \\
5,7508\end{array}$ & $\begin{array}{c}19,7881 \\
5,4376\end{array}$ & $\begin{array}{c}18,5563 \\
5,7638\end{array}$ & $\begin{array}{c}19,4834 \\
3,5097\end{array}$ & $\begin{array}{c}136,5894 \\
26,9417\end{array}$ \\
\hline
\end{tabular}




\begin{tabular}{lcccccccc}
\hline Male & $\begin{array}{c}\text { Mean } \\
\text { St. } \\
\text { Deviatio } \\
\text { n }\end{array}$ & $\begin{array}{c}43,4103 \\
9,8025\end{array}$ & $\begin{array}{c}21,8448 \\
4,7191\end{array}$ & $\begin{array}{c}18,0207 \\
5,8041\end{array}$ & $\begin{array}{c}21,6552 \\
4,8476\end{array}$ & $\begin{array}{c}19,5069 \\
5,3553\end{array}$ & $\begin{array}{c}19,7034 \\
4,4792\end{array}$ & $\begin{array}{c}144,1414 \\
24,9906\end{array}$ \\
\hline p- value & & 0,118 & 0,122 & $0.000^{*}$ & $0.000^{*}$ & 0,086 & 0,600 & $0,004^{*}$ \\
\hline
\end{tabular}

Source: Prepared by the authors

Male individuals" "external regulation", "introjections" sub-dimension and "SM scale" total scores are higher than female individuals' $(p<0,05)$. In other sub-dimensions, no statistically significant difference was found according to gender $(p>0,05)$.

Table 12. Findings Regarding the Sports Motivation Scale and Sub-Dimension Scores of the Participants by Age

\begin{tabular}{|c|c|c|c|c|c|c|c|c|}
\hline Age & & $\begin{array}{c}\text { Knowing } \\
\text { Achievin } \\
\quad \mathrm{g}\end{array}$ & $\begin{array}{l}\text { Stimulati } \\
\text { ng Living }\end{array}$ & $\begin{array}{c}\text { External } \\
\text { Regulatio } \\
\mathbf{n}\end{array}$ & $\underset{\mathbf{n}}{\text { Introjectio }}$ & $\begin{array}{l}\text { Identificati } \\
\text { on }\end{array}$ & $\underset{n}{\text { Amotivatio }}$ & $\begin{array}{c}\text { SM } \\
\text { Scale }\end{array}$ \\
\hline \multirow[t]{2}{*}{15} & Mean & 43,6496 & 21,3942 & 16.3577 & 21,1752 & 19,0219 & 20.5547 & $\begin{array}{c}142,153 \\
3\end{array}$ \\
\hline & St. Dev. & 9,3097 & 4.5783 & 5,3656 & 4.6239 & 5.6078 & 3.4914 & 24,1837 \\
\hline \multirow{2}{*}{16} & Mean & 44,0075 & 22,0373 & 17,6269 & $2, .2761$ & 19,7761 & 19,7836 & $\begin{array}{c}144,507 \\
5\end{array}$ \\
\hline & St. Dev. & 10,3796 & 5.3076 & 6,0271 & 5,2334 & 5,4726 & 4,2041 & 26,5830 \\
\hline \multirow{2}{*}{17} & Mean & 41,2500 & 21,4924 & 17,5379 & 20,7197 & 18,9470 & 18,9318 & 138,8788 \\
\hline & St. Dev. & 10,3240 & 5,1236 & 6,2473 & 5,7496 & 5,6098 & 4,4946 & 27,1681 \\
\hline \multirow[b]{2}{*}{18} & Mean & 41,7632 & 20.9474 & 18.3947 & 20.5526 & 18.4737 & 18,1579 & 138,2895 \\
\hline & $\underset{\text { St. }}{\text { Deviatio }}$ & 8,3647 & 4.6496 & 5,5094 & 4.2215 & 4,9360 & 4.4389 & 24,5201 \\
\hline $\begin{array}{l}\text { p- } \\
\text { valu }\end{array}$ & & 0,085 & 0,578 & 0,140 & 0,748 & 0,469 & $0,001 *$ & 0,281 \\
\hline
\end{tabular}

Source: Prepared by the authors

According to the age of the individuals, the total scores of the amotivation subdimension show a statistically significant difference $(p<0,05)$. According to this, it is concluded that as the age of the individuals increases, the total scores of the non-motivation sub-dimension decrease, that is, the feelings of motivation increase as the age increases. Other sub-dimensions and SG scale do not differ according to age $(p>0,05)$. 
Table 13 - Findings Regarding the Sports Motivation Scale and Sub-Dimension Scores of the Participants by Sport Branch

\begin{tabular}{lcccccccc}
\hline $\begin{array}{l}\text { Sport } \\
\text { branch }\end{array}$ & & $\begin{array}{c}\text { Knowin } \\
\text { Achievin }\end{array}$ & $\begin{array}{c}\text { Stimulati } \\
\text { ng Living }\end{array}$ & $\begin{array}{c}\text { External } \\
\text { Regulatio } \\
\mathbf{n}\end{array}$ & $\begin{array}{c}\text { Introjectio } \\
\mathbf{n}\end{array}$ & $\begin{array}{c}\text { Identificati } \\
\text { on }\end{array}$ & $\begin{array}{c}\text { Amotivatio } \\
\text { n }\end{array}$ & $\begin{array}{c}\text { SM } \\
\text { Scale }\end{array}$ \\
\hline $\begin{array}{l}\text { Individu } \\
\text { al Sports }\end{array}$ & $\begin{array}{c}\text { Nea } \\
\text { St. }\end{array}$ & 42,0891 & 21,2574 & 16,1238 & 20,5050 & 18,6683 & 19,9653 & $\begin{array}{c}138,608 \\
9\end{array}$ \\
& Dev. & 10,1609 & 5,1061 & 5,8437 & 5,0777 & 5,6281 & 3,6053 & 25,6968 \\
\hline $\begin{array}{l}\text { Team } \\
\text { Sports }\end{array}$ & $\begin{array}{c}\text { Mea } \\
\text { St. }\end{array}$ & 43,5439 & 21,8536 & 18,2427 & 21,4477 & 19,6151 & 19,3431 & 144,046 \\
& Dev. & 9,6869 & 4,8532 & 5,7306 & 5,1421 & 5,3830 & 4,5816 & 25,8525 \\
\hline p- value & & 0,125 & 0,210 & $0.000^{*}$ & 0,054 & 0,072 & 0,119 & $0,028^{*}$ \\
\hline
\end{tabular}

Source: Prepared by the authors

The external regulation sub-dimension and SM scale total score values of individuals interested in team sports were higher than individuals interested in individual sports $(p<0,05)$. In other sub-dimensions, no significant difference was found according to the sport branch $(\mathrm{p}>0,05)$.

Table 14 - Findings Regarding the Sports Motivation Scale and Sub-Dimension Scores of the Participants according to Active Sports Duration

\begin{tabular}{|c|c|c|c|c|c|c|c|c|}
\hline $\begin{array}{l}\text { Activ } \\
\text { e } \\
\text { Sport }\end{array}$ & & $\begin{array}{c}\text { Knowing } \\
\text { Achievin } \\
\text { g }\end{array}$ & $\begin{array}{c}\text { Stimulatin } \\
\text { g Living }\end{array}$ & $\begin{array}{c}\text { External } \\
\text { Regulatio } \\
\mathbf{n}\end{array}$ & $\begin{array}{c}\text { Introjectio } \\
\mathbf{n}\end{array}$ & $\begin{array}{l}\text { Identificatio } \\
\text { n }\end{array}$ & $\begin{array}{c}\text { Amotivatio } \\
\mathbf{n}\end{array}$ & $\begin{array}{c}\text { SM } \\
\text { Scale }\end{array}$ \\
\hline \multirow{2}{*}{$\begin{array}{l}0-5 \\
\text { years }\end{array}$} & $\begin{array}{c}\text { Mea } \\
\text { n }\end{array}$ & 42,9116 & 21,6429 & 16,7245 & 20,7585 & 19,1769 & 19,7483 & $\begin{array}{c}140,962 \\
6\end{array}$ \\
\hline & $\begin{array}{c}\text { St. } \\
\text { Dev. }\end{array}$ & 9,9321 & 4,8911 & 5,7918 & 5,1469 & 5,5535 & 4,0005 & 25,7678 \\
\hline \multirow{2}{*}{$\begin{array}{l}6 \\
\text { years } \\
\text { and } \\
\text { more }\end{array}$} & $\begin{array}{c}\text { Mea } \\
\mathbf{n}\end{array}$ & 42,8095 & 21,4558 & 18,3673 & 21,5306 & 19,1905 & 19,3878 & $\begin{array}{c}142,741 \\
5\end{array}$ \\
\hline & $\begin{array}{c}\text { St. } \\
\text { Dev. }\end{array}$ & 9,9356 & 5,1501 & 5,8976 & 5,0698 & 5,4425 & 4,4942 & 26,1939 \\
\hline \multicolumn{2}{|c|}{ p-value } & 0,919 & 0,710 & $0,005^{*}$ & 0,136 & 0,981 & 0,393 & 0,497 \\
\hline
\end{tabular}

Source: Prepared by the authors

The external regulation sub-dimension total score values of individuals who have been doing sports for 6 years or more were higher than those who have been doing sports for 5 or less years $(\mathrm{p}<0,05)$. In other sub-dimensions and SM scale, no significant difference was found according to active sports duration $(\mathrm{p}>0,05)$. 
Table 15 - Findings Regarding the Motivation Scale and Sub-Dimension Scores of the Participants according to the Number of Days Doing Sports in a Week

\begin{tabular}{|c|c|c|c|c|c|c|c|c|}
\hline $\begin{array}{l}\text { Numbe } \\
\text { r of } \\
\text { sports } \\
\text { days } \\
\text { per } \\
\text { week }\end{array}$ & & $\begin{array}{c}\text { Knowi } \\
\text { ng } \\
\text { Achievi } \\
\text { ng }\end{array}$ & $\begin{array}{l}\text { Stimulati } \\
\text { ng Living }\end{array}$ & $\begin{array}{c}\text { External } \\
\text { Regulati } \\
\text { on }\end{array}$ & $\begin{array}{l}\text { Introjecti } \\
\text { on }\end{array}$ & $\begin{array}{l}\text { Identificati } \\
\text { on }\end{array}$ & $\begin{array}{c}\text { Amotivati } \\
\text { on }\end{array}$ & $\begin{array}{c}\text { SM } \\
\text { Scale }\end{array}$ \\
\hline \multirow[b]{2}{*}{$\begin{array}{l}1-2 \\
\text { days }\end{array}$} & Mean & $\begin{array}{c}40,864 \\
9\end{array}$ & 20,9369 & 16,5315 & 20.2342 & 18,4865 & 19,3423 & $\begin{array}{c}136,39 \\
64\end{array}$ \\
\hline & $\begin{array}{c}\text { St. } \\
\text { Deviation }\end{array}$ & $\begin{array}{c}10,536 \\
0\end{array}$ & 5,2384 & 6,0839 & 5.0469 & 5,8432 & 4,5196 & $\begin{array}{c}27,711 \\
5\end{array}$ \\
\hline \multirow{2}{*}{ After } & Mean & $\begin{array}{c}43,620 \\
7\end{array}$ & 21,0000 & 16,9064 & 20,8177 & 19,4236 & 19,6847 & $\begin{array}{c}142,04 \\
43\end{array}$ \\
\hline & $\begin{array}{c}\text { St. } \\
\text { Deviation }\end{array}$ & $\begin{array}{c}10,101 \\
9\end{array}$ & 5,0383 & 5,9864 & 5,4447 & 5,2706 & 3,8587 & $\begin{array}{c}26,084 \\
4\end{array}$ \\
\hline \multirow{2}{*}{$\begin{array}{l}5-6 \\
\text { days }\end{array}$} & Mean & $\begin{array}{c}43,628 \\
3\end{array}$ & 21,5911 & 18,6283 & 22,1150 & 19,3363 & 19,7876 & 145,7611 \\
\hline & $\begin{array}{c}\text { St. } \\
\text { Deviation }\end{array}$ & 8,8117 & 5,0350 & 5,4103 & 4,4596 & 5,7501 & 4,4590 & 23,3311 \\
\hline \multirow{2}{*}{$\begin{array}{l}7 \\
\text { days }\end{array}$} & Mean & $\begin{array}{c}42,000 \\
0\end{array}$ & 22,2655 & 17,5000 & 21,2143 & 19,9286 & 19,6281 & 141,4286 \\
\hline & $\begin{array}{c}\text { St. } \\
\text { Deviation }\end{array}$ & 9,4462 & 4,5434 & 4,6863 & 5,1317 & 4,0660 & 4,1699 & 23,4511 \\
\hline $\begin{array}{l}p \text { - } \\
\text { value }\end{array}$ & & 0,091 & 0,242 & 0,055 & 0,064 & 0,476 & 0,864 & 0,078 \\
\hline
\end{tabular}

Source: Prepared by the authors

The number of days in a week that individuals do sports does not make a statistically significant difference on the SG scale and its sub-dimensions $(\mathrm{p}>0,05)$.

\section{Pearson coefficient of the relationship between the panas scale and the sports motivation scale}

Table 16 - The Relationship Between Total Panas Scale Scores and Sport Motivation Scale

\begin{tabular}{c|c} 
& Total Scores \\
& SportS Motivation Scale \\
\hline Panas Scale & $0,334^{* *}$ \\
\hline Positive Emotion & $0,462^{* *}$ \\
& $(0.000)$ \\
Negative Emotion & $-0,272^{* *}$ \\
& $(0,000)$
\end{tabular}

*Correlation is significant at the 0,01 level

Source: Prepared by the authors 
When the correlation table above was examined, a positive relationship was obtained between the Panas scale and the sports motivation scale. In addition, a positive relationship was achieved between the positive emotion sub-dimension and the SM scale, and a negative relationship between negative emotion and the sports motivation scale. An increase in the intensity of positive emotions of individuals increases their motivation in sports, while an increase in the intensity of negative emotions decreases motivation in sports.

\section{Discussion and Conclusion}

In this section, the discussion and interpretation of the findings that emerged as a result of the analysis of the data from the research are included.

There is a significant difference in the Panas scale and sub-dimension scores of the individuals at the $95 \%$ confidence level according to their gender $(p<0,05)$. Accordingly, men's positive emotion intensity is higher than women's, and women's negative emotion intensity is higher than men. Also, men have higher Panas scale scores than women and men have higher overall emotional intensity than women. It is seen that there are different opinions about the gender factor. The study conducted by Martinović et al. with 706 primary school students aged between 11 and 14, and it was observed that there were statistically significant differences between girls and boys. Boys scored higher than girls. Şirin et al. (2008) revealed that there is a statistically significant difference in favor of female students in the subdimensions of "entertainment", "competition" and "acting/being active" between male and female students when the gender difference is examined.

Individuals' Panas scale and sub-dimension scores do not show a statistically significant difference according to their age ( $>00.05)$. Altıntaş et al. (2010), Salguero et al. (2004), Arslan and Altay (2009) studied the motivation of students to participate in sports in all sports branches. They found the most important reasons for participation as skill development and competition. Soyer et al. (2010) did not find a significant relationship between the ages of the participants and their motivation for success. These studies show parallelism with our study. The total scores of positive emotions and panas scale of individuals engaged in team sports are higher than individuals engaged in individual sports $(p<0,05)$. Individuals' negative emotion scores do not differ according to the sport branch $(\mathrm{p}>0,05)$.

Individuals' Panas scale and sub-dimension scores do not differ significantly according to their active sport duration $(p>0,05)$. Individuals' Panas scale and negative 
emotion scores do not differ according to the number of sports they do per week $(p>0,05)$. However, it was concluded that as the number of days of exercise in a week increases, the positive emotions of individuals also increase. Male individuals' "external regulation", "introjection" sub-dimension and "SM scale" total scores are higher than female individuals' ( $\mathrm{p}<0,05)$. In other sub-dimensions, no statistically significant difference was found according to gender ( $>0.05)$. While Yigit (2019), Gacar (2013), Kılınç et al. (2012) determined that there was no difference in terms of gender in their studies examining the motivation levels of athletes, in the study conducted by Esentürk (2014), male athlete students were found to have higher level of extrinsic motivation than female athletes. In Kazak's (2001) research in which he analyzed the motivational tendencies of elite volleyball players, he revealed that male volleyball players had higher scores than female volleyball players in the introjection subdimension of extrinsic motivation. In Kazak's (2004) research on motivation and gender, a difference was revealed only in the sub-dimensions of external regulation, stimulating living and intrinsic motivation. The results obtained in this study also support our study findings.

According to the age of the individuals, the total scores of the "amotivation" subdimension show a statistically significant difference $(p<0,05)$. According to this, it is concluded that as the ages of the individuals increase, the total scores of the amotivation subdimension decrease, that is, the feelings of motivation increase as the age increases. Other sub-dimensions and SM scale do not differ according to age ( $>00,05)$. The "external regulation" sub-dimension and "SM scale" total score values of individuals engaged in team sports were higher than individuals interested in individual sports $(p<0,05)$. In other subdimensions, no significant difference was found according to the sport branch $(p>0,05)$.

On the basis of the result that the difference between individual sports and team sports psychological well-being of the students participating in the research is not statistically significant, it can be thought that is due to the fact that all of the students are engaged in sports and that the athletes have personality traits. The "external regulation" sub-dimension total score values of individuals who have been doing sports for 6 years or more were higher than those who have been doing sports for 5 or less years $(p<0.05)$. In other sub-dimensions and SM scale, no significant difference was found according to active sports duration ( $>0$,05). Akman and Can (2019) observed that the external motivation level of the students who did orienteering for 5 years or more was higher than the students who were between 1 year and 2-4 years. Besides that, as the number of years of doing sports increases, it is observed that the level of external regulation also increases. There was a difference in external regulation in the sports motivation sub-scale of the students who did individual and team 
sports in the study which was done by Danışman (2011). In other words, as doing sports increases, external regulation increases. These studies support our work. The number of days in a week that individuals do sports does not make a statistically significant difference on the SM scale and its sub-dimensions $(p>0,05)$. An increase in the intensity of positive emotions of individuals increases their motivation in sports, while an increase in the intensity of negative emotions decreases motivation in sports. Motivation is important for ensuring sustainability in sports environments (AKOĞLU et al., 2019).

\section{REFERENCES}

ACAR, E.; YIĞIT, S.; RAMAZANOĞLU, T. M. Investigation of depression levels of 9th and 10th grade high school students who play and do not do sports. The Journal of Academic Social Science, v. 5, n. 61, p. 349-356, 2017.

ADAIR, J. Effective Motivation. Istanbul: BKY, 2003.

AKMAN, K.; CAN, H. C. Examination of sports motivation levels of high school students doing orienteering in terms of different variables, Inonu University. Journal of Physical Education and Sport Sciences (IUJPESS), v. 6, n. 3, p. 12-21, 2019.

AKOĞLU, H. E.; AYYILDIZ, E.; SUNAY, H. Investigation of athletes' divergence in sports and sportsmanship behaviors participating in international sports organizations. sportive perspective. Journal of Sport and Educational Sciences, v. 6, n. 1, p. 329-340, 2019.

ALAEDDINOGLU, V. The effect of children games on psychomotor development. academic research and reviews in the field of sport sciences. İzmir: Wall Publishing House, 2021. p. 1-17.

ALTINTAŞ, A. et al. Investigation of the relationship between young football players' sport participation motivation and perceptions of success. Turkiye Klinikleri Journal of Sport Sciences, v. 2, n. 1, p. 26-31, 2010.

ASLAN, Y.; ALTAY, F. Investigation of Sports Participation Motives of Male Students in Primary School Teams. Celal Bayar University Journal of Physical Education and Sports Sciences, v. 4, n. 2, p. 59-66, 2009.

AYDIN A. Psychology of development and learning. Istanbul: Alfa Publications, 2001.

BUDAK, S. Psychology dictionary. İstanbul: Science and Art Publications, 2001.

BUĞDAYCI, S. Comparison of physical parameters of professional footballers and amateur footballers. 2000. Thesis (Master) - NS. Institute of Health Sciences, Konya, 2000.

CAN, Y. et al. Investigation of the relationship between family-trainer-club support and success motivation in elite taekwondo athletes. International Journal of Human Sciences, Istanbul, v. 6, n. 2, p. 4-6, 2009. 
DALBUDAK, İ.; YIGIT, S. Hearing imparied students' attitudes towards physical education and sports. Journal of Education and Training Studies, v. 7, n. 9, p. 55-60, 2019.

DANIŞMAN, İ.H.A. Investigation of the effects of motivational orientations on anxiety levels of students who do individual and team sports. 2011. Thesis (Master) - Institute of Health Sciences, Gazi University, Ankara, 2011.

DOĞAN, O. Sports Psychology. Adana: Nobel Bookstore, 2005. p. 162.

ESENTURK, O. K. Investigation of motivation and aggression levels of athlete students studying at high school level and participating in inter-school sports competitions. 2014. Thesis (Master) - Institute of Social Sciences, Gazi University, Ankara, 2014.

FRANKEN, R. Human motivation. 3. ed. CA: Brooks/Cole Publishing Co, 1994.

GACAR, A. Examinationos sport-specific achievement motivation level of super league handball players in universities. European Journal of Experimental Biology, v. 3, n. 1, p. $181,2013$.

GENÇÖZ, T. Positive and negative affect scale: validity and reliability study. Turkish Journal of Psychology, v. 15, n. 46, p. 19-26, 2000.

GEORGE, D.; MALLERY, M. SPSS for windows step by step: a simple guide and reference, 17.0 update. 10. ed. Boston: Pearson, 2010.

GEORGE, S. The Motivational Miracle. Translated by Kaplan U. Istanbul: Sistem Publishing, 1997. p. 10-11.

GROSS, J. J. Emotion regulation: Past, present, future. Cognition \& Emotion, v. 13, n. 5, p. $551-573,1999$.

HAZAR, Z.; TEKKURSUN DEMIR, G.; CAN, B. An investigation of high school students' sports participation motivation in terms of different variables. SPORTMETER Journal of Physical Education and Sport Sciences, v. 16, n. 4, p. 225-235, 2018.

KAZAK, Z. F. Motivational orientations of elite athletes: a study on volleyball players. 2001. Thesis (Master0 - Institute of Health Sciences, Mersin University, Mersin, 2001.

KAZAK, Z. F. Reliability and validity study of the sports motivation scale -SHQ- for Turkish athletes. Hacettepe Journal of Sport Sciences, v. 15, n. 4, p. 191-206, 2004.

KILINÇ, M. et al. Examination of the motivation levels of team sports according to different variables. Abant İzzet Baysal University Journal of the Faculty of Education, v. 112, p. 191-206, 2012.

LUG, G. P. et al. Toward a new measure of intrinsic motivation extrinsic motivation and a motivation in sports. The Sports Motivation Scale. Journal of Sports and Exercise Psychology, p. 17-35, 1995. 
MARTINOVIĆ, D.; ILIĆ, J.; VIŠNJIĆ, D. Gender differences in sports involvement and motivation for engagement in physical education in primary school. Problems of Education in the 21st Century, v. 31, 2011.

MYERS, L. B.; DERAKSHAN, N. To forget ot not to forget: what do repressors forget and when they forget? Cognition and Emotion, v. 18, p. 495-511, 2004.

NICHOLS, J. G.; ROBERT, G. C. The general and the specific in the devolopment and expression of achievement motivation; motivation in sport and exercise. Human Kinetics Boxing, p. 65-69, 1992.

NTOUMANIS, N. A prospective study of participation in optional school physical education using a self-determination theory framework. Journal of Educational Psychology, v. 97, n. 3, p. 444, 2005.

PELLETIER, L. G. Toward a new measure of intrinsic motivation, extrinsic motivation and amotivation in sport: the sport motivation scale (SMS). Journal of Sportand Exercise Psychology, v. 17, n. 2, p. 35-53, 1995.

ROBERTS, G. C.; TREASURE, D. C.; CONROY, D. E. Understanding the dynamics of motivation in sportand physicalactivity: an achieve mentgoalinter pretation. In:

TENENBAUM, G.; EKLUND, R. C. (Ed.). Handbook of Sport Psychology. 3. ed. John Wiley \& Sons, 2007. p. 3-10.

SALGUERO, A. et al. Relationship between perceived physical lity and sport parti pation motives in young competitives wimmers. Journal of Sports Medicine and Physical Fitness, v. 44, n. 3, p. 294-299, 2004.

SELCUK, Z. Educational Psychology. Ankara: Pegem, 1996.

ŞIRIN FARUK, E. Determination of Factors Affecting Sports Participation Motivation of High School Students Doing Sports. Niğde University Journal of Physical Education and Sport Sciences, v. 2, n. 2, 2008.

SOYER, F.; CAN, Y.; AKBULUT, K. Investigation of the relationship between the organizational commitment levels of football coaches and their job satisfaction levels. International Journal of Human Sciences, 516526, 2010.

SUNAY, H. Analysis of trainers' wellness in turkey. Acta Medica Mediterranea, v. 36, n. 4, p. 2371-2375, 2020.

TURHAN, M. Investigation of the relationship between depression level, anxiety level and personality traits of professional football players and success motivation in sports. 2009. Thesis (Master) - Maltepe U. Institute of Social Sciences, Istanbul, 2009.

TURKMEN, M. Investigation of success motivation levels of professional male football players and amateur male football players. 2005. Thesis (Master) - Izmir, 2005. 
WATSON, D.; CLARK, L. A.; TELLEGEN, A. Development and validation of brief measures of positive and negative affect: The Panas Scales. Journal of Personality and Social Psychology, v. 54, n. 6, p. 1063-1070, 1988.

WATSON, D.; CLARK, L. A.; TELLEGEN, A. Development and validation of brief measure of positive and negative affect: the Panas scales. Journal of Personality and Social Psychology, v. 54, n. 6, p. 1063-1070, 1988.

YILDIRAN, İ.; YETIM, A. A Research on Primary Objectives of Physical Education Lesson in Secondary Education. G.Ü.BESYO Journal of Physical Education and Sport Sciences, Ankara, v. 1, n. 3, 1996.

\section{How to reference this article}

BALYAN, M.; ÇANKAYA, C. The relationship between positive and negative emotional states and motivation of high school students doing sports. Revista online de Política e Gestão Educacional, Araraquara, v. 25, n. 3, p. 2567-2588, Sep./Dec. 2021. e-ISSN: 15199029. DOI: https://doi.org/10.22633/rpge.v25i3.15842

Submitted: $15 / 09 / 2021$

Required revisions: $12 / 10 / 2021$

Approved: $17 / 11 / 2021$

Published: 08/12/2021 